\title{
KLAUSULA ASURANSI KEMATIAN PADA AKAD KREDIT KPR SUBSIDI DALAM KITAB UNDANG-UNDANG HUKUM DAGANG
}

\author{
Yandri Radhi Anadi \\ Fakultas Hukum Universitas Islam Malang \\ Jalan Mayjen Haryono Nomor 193 Malang \\ Email: yandri@unisma.ac.id
}

\begin{abstract}
Abstrak
Jiwa sesorang dapat diasuransikan untuk keperluan orang yang berkepentingan, baik untuk selama hidupnya maupun untuk waktu yang ditentukan dalam perjanjian. setiap orang yang hidup menghadapi resiko atas hidupnya sendiri, sebab ia tidak mengetahui kapan ia akan meninggal dunia. Resiko yang diderita dapat berupa kerusakan kerugian atau kehilangan, sehingga timbul upaya untuk menghindari dan mengalihkan resiko kepada masyarakat melalui program KPR subsidi. Bagi bank dalam meninggalnya debitur adalah salah satu resiko yang timbul dalam pemberian kredit. Dalam penulisan terdapat permasalah yang dikaji yaitu, bagaimana implementasi asuransi kematian dalam akad kredit KPR subsidi dan seperti apa mekanisme klaim asuransi kematian pasa KPR subsidi. Dalam penelitian ini penulis menggunakan metode penelitian hukum yang bersifat yuridis normatif. Penelitian ini menggunakan pendekatan perundangundangan, pendekatan konseptual, dan pendekatan perbandingan. Sumber bahan hukum dalam peneitian ini menggunakan sumber bahan hukum primer dan sumber bahan hukum sekunder. Untuk Teknik pengumpulan data yang digunkan adalah telaah Pustaka. Implementasi pemberian asuransi kematian Kredit Kepemilikan Rumah (KPR) subsidi, para pihak antara penanggung dan tertanggung harus memperhatikan hal-hal dasar yang dimana sesuai dalam perjanjian serta Mekanisme prosedur klaim asuransi kematian KPR subsidi sama dengan prosedur klaim asuransi jiwa pada umumnya.
\end{abstract}

Kata Kunci: Asuransi Jiwa, Kredit Kepemilikan Rumah Subsidi

\section{Abstract}

The soul of a person can be insured for the needs of the person concerned, both for the duration of his life and for the time specified in the agreement. everyone who lives faces the risk of his own life, because he does not know when he will die. The risk suffered can be in the form of damage, loss or loss, resulting in efforts to avoid and transfer risks to the community through the subsidized KPR program. For banks, the death of a debtor is one of the risks that arise in providing credit. In writing, there are 
problems being studied, namely, how is the implementation of death insurance in the subsidized MORTGAGE credit agreement and what is the mechanism of death insurance claims for subsidized mortgages. In this research, the writer uses a legal research method which is normative juridical. This study uses a statutory approach, conceptual approach, and a comparative approach. The source of legal materials in this research uses primary sources of legal materials and sources of secondary legal materials. For data collection techniques used are literature review.

Keywords: Life Insurance, Subsidized Home Ownership Loans

\section{PENDAHULUAN}

\section{A. Latar Belakang Masalah}

Dalam hakikatnya kehidupan manusia dalam sosial bermasyarakat mengandung berbagai hal yang salah satunya berwujudkan sifat tidak kekal. Hal tersebut memberikan asumsi bahwa sifat tersebut hanya sementara yang merupakan sifat alamai yang tidak dapat dipastikan, kepastian tersebut tidak dapat diwujudkan dalam berbagai bentuk dari suatu peristiwa yang menimbulkan problem dalam diri manusia yang bersifat tidak aman. Sebagai makhluk ciptaan tuhan yang berakal budi pekerti selalu berusaha untuk menghindari suatu permasalahan/resiko yang membuatnya merasa tidak aman sehingga dapat menjadi aman. Setiap yang bernyawa mengahadapi resiko atas hidupnya sendiri, sebab ia tidak memahami dan mengetahui kapan pastinya ia akan meninggalkan dunia atau keluarganya.

Menurut L. Athearnm, resiko merupakan aspek utama dari kehidupan manusia pada umumnya dan merupakan faktor penting dalam asuransi. Resiko merupakan kemungkinan penyimpangan harapan yang tidak menguntungkan, yaitu ketidakpastian suatu peristiwa yang tidak diinginkan. ${ }^{1}$ Dalam lingkup asuransi atau pertanggungan resiko sudah menjadi wadah untuk siap di terima Ketika terjadinya suatu peristiwa yang tidak dapat diharapkan terjadinya kepada orang lain yang mengambil resiko untuk mengganti kerugian.

Resiko yang mungkin dapat diderita berupa kerusakan kerugian atau kehilangan keuntungan yang diharapkan sehingga menyebabkan timbulnya upaya untuk menghindari dan mengalihkan resiko kepada pihak lain yang bersedia menanggungnya, dalam hal ini adalah pihak asuransi. Hal yang dimaksud demikian untuk memberikan perlindungan akan rasa aman kepada masyarakat, yaitu dengan mengadakan suatu perjanjian pelimpahan resiko

${ }^{1}$ Sri Rejeki Hartono, Hukum Asuransi dan Perusahaan Asuransi, Jakarta: Sinar Grafika, 2001, h. 58. 
dengan pihak lain. Dengan demikian perjanjian yang semacam ini disebut perjanjian asuransi. ${ }^{2}$

Asuransi (pertanggungan) adalah perjanjian dua pihak, yaitu perusahaan asuransi dan pemegang polis, yang menjadi dasar bagi penerimaan premi oleh perusahaan asuransi sebagai imbalan untuk memberikan penggantian kepada tertanggung atau pemegang polis karena kerugian, kerusakan, biaya yang tmbul, kehilangan keuntungan, atau tanggung jawab hukum kepada pihak ketiga yang mungkin diderita tertanggung atau pemegang polis karena terjadinya suatu peristiwa yang tidak pasti, atau memberikan pembayaran yang didasarkan pada hidupnya tertanggung dengan manfaat yang besarnya telah ditetapkan atau didsarkan pada hasil pengelolaan dana. ${ }^{3}$

Demikian dalam tujuannya asuransi, yaitu mengalihkan resiko yang timbul dalam suatu peristiwa-peristiwa yang tidak dapat diharapkan terjadinya itu kepada orang lain yang mengambil resiko untuk mengganti kerugian. ${ }^{4}$ Dalam asuransi yang merupakan terjemahan dari insurance atau verzekering atau assurantie, timbul karena kebutuhan manusia. ${ }^{5}$ Baik asuransi pada umumnya maupun asuransi jiwa pada khususnya merupakan perjanjian timbal balik antara penanggung dan tertanggung dengan meneri premi asuransi untuk memberikan penggantian kepada pihak teranggung karena kerusakan, kerugian, atau kehilangan keuntungan yang diharpakan ada pertanggungjawaban hukum kepada tertanggung yang mungkin akan dialami dari timbulnya suatu peristiwa yang tidak pasti yang didasarkan atas meninggal atau hidupnya orang yang dipertanggungkan.

Perjanjian asuransi sebagai lembaga pengalihan serta pembagian resiko akan mempunyai kegunaan positif bagi masyarakat, perusahaan maupun bagi pembangunan negara. Mereka yang melakukan perjanjian asuransi akan memiliki rasa aman dan tentram sebab dalam melakukan perjanjian asuransi mendapatkan perlindungan dari memungkinkan terjadinya suatu kerugian. Perusahaan yang mengalihkan resikonya melalui perjanjian asuransi akan dapat meningkatkan usahanya dan berani menggalang tujuan yang lebih besar. Demikian pula terhadap premi-premi yang terkumpul dalam suatu perusahaan asuransi dapat diusahakan dan Cipta, 2000,

${ }^{2}$ Djoko Prakoso dan I Ketut Murtika, Hukum Asuransi Indonesia, Jakarta: Rineka h. 8.

${ }^{3}$ Pasal 1 Ayat (1) Undang-Undang Nomor 40 Tahun 2014 Tentang Perasuransian. UGM, 1990,

${ }^{4}$ Emmy Pangaribuan Simanjuntak, I, Hukum Pertanggungan, Yogyakarta: FH

h. 5 .,

5 Man Suparman Sastrawidjaja, Aspek-Aspek Hukum Asuransi dan Surat Berharga, Bandung: Alumni, 1997, h. 1. 
digunakan sebagai dana untuk usaha pembangunan, dan hasilnya tersebut dapat dirasakan oleh masyarakat sebagai pengguna jasa asuransi. Dengan itu pada pihak lain resiko yang akan mungkin terjadi dalam pelaksanaan pembangunan juga dapat dialihkan kepada perushaan asuransi.

Perkembangan usaha perasuransian mengikuti perkembangan ekonomi masyarakat, dengan berkembanganya jumlah populasi manusia untuk itu semakin meningkat juga kebutuhannya, saat ini kebutuhan dasar yang paling banyak ialah kebutuhan tempat tinggal. Bank sebagai penghimpun dan penyalur dana bagi masyarakat yang membutuhkan yang dimana dalam salah satu dari programnya yaitu memberikan Kredit Pemilikan Rumah (KPR) yang sebagaimana dutunjukan untuk pembelian bangunan rumah atau tempat tinggal.

Pemberian kredit oleh bank dilakukan dilakukan dengan prinsip kehati-hatian, prinsip kehati-hatian dilakukan melalui analisa yang akurat dan mendalam melalui penyaluran yang tepat, pengawasan dan pemantauan yang baik, perjanjian yang sah dan memenuhi syarat hukum, serta pengikatan serta jaminan yang kuat disertai dokumentasi perkreditan yang teratur dan lengkap. Semua itu bertujuan agar kredit yang disalurkan tersebut dapat kembali dengan tepat waktu sesuai dengan perjanjian yang meliputi pinjaman pokok dan bunga. ${ }^{6}$

Dengan mempertimbangkan hal demikian akan terjadinya resiko dalam pemberian Kredit Kepemilikan Rumah (KPR), bank sebagai jasa penyalur dana kredit harus dapat menghilangkan atau paling tidak mengulangi resiko yang mungkin timbul dalam setiap pembelian kredit. Salah satu caranya adalah mengalihkan resiko tersebut kepada pihak lain, yang memang dimungkinkan baik dari segi yuridis (peraturan) maupun dari segi bisnis yang tidak lain adalah asuransi. ${ }^{7}$

Dalam asuransi jiwa pada umumnya dalam pemberian Kredit Kepemilikan Rumah (KPR), pihak penerima manfaat atau yang ditunjuk adalah pihak bank (kreditur), sedangkan pihak kreditur tetap menjadi pihak yang tertanggung. Bagi bank sebagai kreditur, meninggalnya penerima kredit merupakan salah satu resiko yang timbul dalam pemberian kredit. Dalam rangkan untuk mencegah terjadinya suatu permasalahan tersebut dikemudian hari dikenal adanya suatu proteksi kematian dari penerima kredit dimana jumlah uang pertanggungan dikaitkan dengan jumlah kredit yang terpaut, sedangkan besarnya premi dihitung dari jumlah uang pertanggungan.

6 Sutomo, Jaminan Aspek-Aspek Hukum Perkreditan Pada Bank, Bandung: Alfabeta, 2004, h. 2.

${ }^{7}$ Hasanuddin Rahman, Aspek-Aspek Hukum Pemberian Kredit Perbankan Di Indonesia, Bandung: Citra Aditya Bakti, 1998, h. 245. 
Asuransi jiwa pada umumnya hanya mengenal pihak penanggung (pihak asuransi jiwa), pihak tertanggung (orang yang jiwanya dipertanggungkan), dan pihak pemberi manfaat/yang ditunjuk (orang yang berhak menerima pembayaran uang santunan) biasanya ahli waris dari tertanggung. Dalam asuransi jiwa pada perjanjian kredit kepemilikan rumah (KPR), pihak penerima manfaat yang ditunjuk adalah pihak bank/kreditur, sedangkan pihak debitur teap menjadi pihak tertanggung. Dengan hal demikian bagi bank, meninggalnya penerima kredit merupakan salah satu resiko yang timbul dalam pemberian kredit. Dalam rangka menggulangi masalah tersebut, dikenal adanya suatu proteksi kematian dari penerima kredit dimana jumlah uang pertanggungan dikaitkan dengan jumlah kredit yang terpaut, sedangkan besarnya premi dihitung dari jumlah uang pertanggungan untuk tiap bulan.

Jenis jaminan dalam pertangggungan yang mana memberikan jaminan dalam hal pada saat jangka waktu masih berjalan, penerima kredit tersebut meninggal dunia, sebagai the key man yang mana tidak ada orang lain yang dapat bertanggungjawab atas pengambilan kredit dimaksud sepeninggalnya tertanggung, maka seketika itu juga kredit masih berjalan, pelunasannya diambil oleh perusahaan asuransi jiwa yang bersangkutan sebagai uang santunan yang hanya dipergunakan untuk melunasi kredit yang diterima tertanggung. ${ }^{8}$ Namun demikian dalam kewajiban pengembalian kredit ada kalanya pihak perusahaan asuransi jiwa berbeda pendapat dengan penerima manfaat.

\section{B. Rumusan Masalah}

Dari uraian latar belakang diatas penulis merasa perlu untuk mengkaji permasalahan yaitu, bagaimana implementasi asuransi kematian dalam akad kredit KPR subsidi dan seperti apa mekanisme klaim asuransi kematian pasa KPR subsidi.

\section{METODE PENELITIAN}

Metode pendekatan yang digunakan dalam penelitian ini adalah bersifat yuridis normatif. Penelitian hukum normatif dilakukan untuk mengkaji atau meneliti bahan pustaka atau data normatif dilakukan mengutamakan cara meneliti bahan pustaka atau data sekunder yang meliputu bahan hukum primer dan bahan hukum sekunder.

Penelitian hukum normatif ini dilakukan dengan mengkaji atau melakukan analisis hukum, menemukan permasalahan hukum dari pemberian asuransi dari kredit kepemilikan rumah (KPR), serta pendekatan perundang-undangan khsusnya yang berkaitan dengan hukum asuransi.

${ }^{8}$ Ibid, h. 245 
Pendekatan yuridis normatif yaitu untuk menguji dan menerapkan prinsipprinsip hukum asuransi.

Penelitian ini menggunakan 4 (empat) macam pendekatan, yakni pendekatan perundang-undangan (case approach), pendekatan konseptual (conseptual approach), dan pendekatan perbandingan. Penelitian hukum normatif tidak mengenal adanya data-data untuk itu guna memecahkan permasalahan hukum yang dikaji serta memberikan penjelasan mengenai apa yang seharusnya diperlukan sumber-sumber penelitian. Sumber bahan hukum dalam peneitian ini menggunakan sumber bahan hukum primer dan sumber bahan hukum sekunder.

Penelitian ini adalah penelitian kepustakaan. Bahan hukum yang dihimpun dalam penelitian ini dihasilkan dari kepustakaan. Untuk itu Teknik pengumpulan data yang digunkan dalam penelitian ini adalah telaah pustaka. Pengumpulan bahan hukum dilakukan dengan cara penelusuran prinsip dan norma-norma yang mengatur tentang asuransi, dan menganalisis secara mendalam sehingga dapat menjawab rumusan masalah.

\section{PEMBAHASAN}

\section{Implementasi Asuransi Kematian Dalam Akad Kredit KPR Subsidi}

Asuransi sebagai lembaga penyerap dana dari masyarakat, dalam lingkungan sosial masyarakat yang sudah maju dan sadar akan nilai kegunaan lembaga asuransi atau pertanggungan sebagai lembaga pelimpahan resiko, setiap kemungkinan terhadap bahaya menderita kerugian itu pasti diasuransikan atau dipertanggungkan. Hampir disetiap gerak dan aktivitas baik pribadi atau badan-badan usaha itu selalu dilindungi oleh suatu perjanjian pertanggungan yag mereka adakan ataupun dalam asumsi lain setiap kemungkinan resiko itu selalu dipertanggungkan.

Disadari bahwa asuransi mempunyai beberapa manfaat yang antara lain, pertama, membantu masyarakat dalam rangka mengatasi sefala masalah resiko yang dihadapinya. Hal itu akan memberikan ketengan dan kepercayaan diri yang lebih tinggi kepada yang bersangkutan. Kedua, asuransi merupakan sarana pengumpulan dana yang cukup besar sehingga dapat dimanfaatkan untuk kepentingan masyarkat dan pembangunan. Ketiga, sebagai sarana untuk mengatasi resiko-resiko yang dihadapi dalam dalam melaksanakan pembangunan. Selain itu, meskipun banyak metode untuk menangani resiko, asuransi merupakan metode yang paling banyak dipakai. ${ }^{9}$

Perasuransian sebagai lembaga peralihan resiko merupakan suatu manifestasi dari usaha manusia untuk mengalihkan resiko yang seharusnya

${ }^{9}$ M. Suparman, dan Ending, Hukum Asuransi, Bandung: Alumni, 1993, h. 116. 
ditanggung sendiri kemudian dialihkan kepihak lain melalui suatu perjanjian asuransi, yang dalam kegiatan ini disebut dengan risk management. Dalam suatu sisi lain terdapat salah satu jenis asuransi yaitu asuransi jiwa. Asurnsi jiwa merupakan suatu alat penggerak social dan ekonomi, ia merupakan cara sekolompok seseorang untuk dapat bekerja sama memeratakan beban kerugian karena kematian sebelum waktunya dari anggota dalam suatu kelompok.

Asuransi atau pertanggungan didalamnya terdapat akibat hukum tersendiri apabila sesorang sebagai tertanggung yang sudah mendaftarkan asuransi kematian, Asuransi jiwa sendiri sangat penting bagi sesorang ketika masih hidup untuk didaftarkan, karena pada dasarnya asuransi jiwa memberikan perlindungan akibat resiko yang diderita ketika tertanggung meninggal dunia. Jelaslah sebagaimana dalam implementasi hukumnya setiap orang dapat mengasuransikan jiwanya, bahkan asuransi jiwa diadakan untuk kepentingan pihak ketiga, dan juga dapat dilakukan selama hidup atau selama jangka waktu tertentu yang sudah ditetapkan dalam perjanjian.

Dengan demikian, semakin seseorang dalam jiwa pribadinya merasakan tidak aman, denganya semakin itu juga seseorang akan selalu berusaha mengasuransikan segala kemungkinan resiko yang mungkin timbul. Semkain banyak yang merasa tidak aman akan semakin banyak yang mengalihkan resiko kepada pihak lain, untuk itu berarti makin banyak perjanjian asuransi yang ditutup. Selanjutnya makin banyak pula dan yang diserap oleh perusahaan sebagai pembayaran atas kesediaanya mengambil alih resiko pihak tertanggung.

Dalam asuransi jiwa yang dipertanggungkan ialah yang disebabkan oleh kematian (death). Kematian tersebut mengakibatkan hilangnya pendapatan seseorang atau suatu keluarga tertentu, resiko yang mungkin timbul pada asuransi jiwa terutama terletak pada unsur waktu/time, oleh karena itu sulit untuk mengetahui kapan seseorang meninggal dunia. Untuk memperkecil resiko tersebut, maka sebaiknya diadakan pertanggungan jiwa. ${ }^{10}$ Asuransi jiwa merupakan perjanjian timbal balik antara pengambil asuransi dengan penanggung, dimana pengambil asuransi mengikatkan diri untuk membayar uang premi, sedangkan penanggung mengikatkan diri untuk membayar sejumlah uang yang jumlahnya sudah ditetapkan pada saat ditutupnya asuransi atas hidup dan matinya seseorang yang ditunjuk.

Sebagaimana dalam ketentuan pengaturanya yang tercantum dalam Kitab Undang-Undang Hukum Dagang hanya sedikit pembahasanya yang terkait dengan asuransi jiwa, ketentuanya pengaturanya mulai dari pasal 302 sampai dengan 308. Sebagaiman dalam definisnya asuransi jiwa yang

10 A. Abbas Salim, Dasar-Dasar Asuransi, Principle of Insurance, Jakarta: RajaGrafindo Persada, 1995, h. 25. 
menyatakan adalah, jiwa sesorang dapat diasuransikan untuk keperluan orang yang berkepentingan, baik untuk selama hidupnya maupun untuk waktu yang ditentukan dalam perjanjian. ${ }^{11}$ dalam ketentuan Pasal 302 Kitab Undang-Undang Hukum Dagang tersebut, menekankan kepada suatu waktu yang ditentukan dalam asuransi jiwa, sedangkan untuk waktu selama hidupnya tertanggung tidak ditetapkan dalam perjanjian.

Sifat dasar asuransi jiwa ialah proteksi terhadap kerugian finansial akibat hilangnya kemampuan menghasilkan pendapatan yang disebabkan oleh kematian maupun usia lanjut. Proteksi tersebut dapat diperoleh dari perusahaan asuransi jiwa. Menurut Undang-Undang Nomor 2 Tahun 1992 Tentang Usaha Perasuransian yang sudah diubah dengan Undang-Undang Nomor 40 Tahun 2014 Tentang Usaha Perasuransian menyebutkan bahwa asuransi atau pertanggungan jiwa adalah perjanjian antara dua pihak atau lebih, dengan mana pihak penanggung mengikatkan diri kepada tertanggung dengan menerima premi asurnsi, untuk memberikan suatu pembayaran yang didasarkan atas meninggal atau hidupnya seseorang yang dipertanggungkan ${ }^{12}$.

Asuransi jiwa ini termasuk kedalam golongan asuransi yang jenisya lain dari pada asuransi kerugian yaitu yang disebut schadeverzekering didalam beberapa literatur seperti oleh Vollmar. ${ }^{13}$ Schadeverzekering secara luas dapat diartikan sebagai suatu perjanjian dimana satu pihak mengikatkan dirinya untuk membayar sejumlah uang secara sekaligus atau periodic, sedangkan pihak lain mengikatkan dirinya untuk membayar premi dan pembayarn uang itu adalah tergantung kepada mati atau hidupnya seseorang tertentu atau lebih. Salah satu dalam perjanjian tersebut ialah lijfrente yang dikenal dalam KUHPerdata.

Dalam dunia asuransi, khsusnya asurnasi jiwa (kematian) terdapat banyak bentuk asuransi jiwa yang diberikan jaminan atas akibat dari suatu peristiwa kepada sesorang yang tertanggung dengan memberikan sebuah keuntungan, dalam hal ini salah satunya adalah asuransi jiwa terhadap Kredit Kepemilikan Rumah (KPR). Kredit Kepemilikan Rumah (KPR) sendiri dalam tafsiran hukum mempunyai pengertian yang sebagaimana artinya yaitu, kredit yang diberikan oleh bank untuk membantu anggota masyarakat guna membeli sebuah rumah berikut tanahnya untuk dimiliki dan dihuni sendiri. Dengan demikian dalam Kredit Kepemilikan Rumah sendiri terdapat suatu jenis KPR yaitu KPR subsidi. KPR subsidi umumnya Perasuransian.

11 Pasal 302 Kitab Undang-Undang Hukum Dagang.

12 Pasal 1 Ayat (1) Undang-Undang Nomor 2 Tahun 1992 Tentang Usaha

13 Emmy Pangaribuan Simanjuntak, II, Beberapa Aspek Hukum Dagang di Indonesia, Jakarta: Bina Cipta, 1997, h. 91. 
ditunjukan untuk MBR, KPR subsidi disediakan oleh bank Sebagian dari program pemerintah untuk membantu mendanai kepemilikan rumah masyrakat yang akan diberikan subsidi berupa keringanan kredit atau uang muka.

Sebagaimana dalam ketentuan Peraturan Menteri Pekerjaan Umum Dan Perumahan Rakyat, KPR bersubsidi bertujuan untuk memfasilitasi kepemilikan rumah yang layak huni (sehat) dengan maksud membantu kalangan masyarakat berpenghasilan rendah yang selama ini kesulitan mengakses pembiayaan perumahan, sehingga masyarakat berpenghasilan rendah diharapkan dapat meningkatkan produktifitas dari dan keluarganya agar suatu saat dapat mencapai kehidupan yang lebih baik.

Untuk ketetapan sasaran dalam penerima KPR bersubsidi diukur dengan kelompok sasaran yang telah ditetapkan dalam Keputusan Menteri Pekerjaan Umum dan Perumahan Rakyat Nomor 242/KPTS/M/2020, dihitung berdasarkan seluruh pendapatan bersih yang bersumber dari: ${ }^{14}$

a. Gaji, upah, dan/atau hasil usaha sendiri untuk yang berstatus tidak kawin; atau

b. Gaji, upah, dan/atau hasil usaha gabungan untuk pasangan suami istri.

Disisi lain yang haurs diperhatian dari ketentuan dalam pemberian KPR bersubsidi tersebut harus mempunyai pemahaman terhadap perumahan, strategi pilihan, dan investasi rumah tangga untuk mempertimbangkan keuangan. Perumahan sebagai tempat tinggal sendiri rata alokasi untuk biayanya sebesar 10-15\% dari pendapatan rumah tangga, selanjutnya pemahaman perumahan sebagai komoditas, Langkah ini menawarkan keamanan financial dan status soial, serta poin yang terakhir yaitu pemahaman terhadap perumahan sebagai investasi, hal ini merupakan alat investasi dengan prospek tingkat pengembalian yang menguntungkan seiring dengan peningkatan harga lahan dari waktu ke waktu.

Teruntuk demikian sektor perbankan yang berfungsi sebagai lembaga perantara keuangan mempunyai perantara yang strategis terutama menghimpun dan menyalurkan kredit. Kredit Kepemilikan Rumah (KPR) bank memegang peranan penting dalam rangka pembangunan ekonomi secara keseluruhan khususnya dalam menekan inflasi. Sesuai dengan tugas

14 Diktum Kesatu Huruf A Angka 1 Keputusan Menteri Pekerjaan Umum dan Perumahan Rakyat Nomor 242/Kpts/M/2020 Tentang Batasan Penghasilan Kelompok Sasaran Kredit/Pembiayaan Pemilikan Rumah Bersubsidi, Besaran Suku Bunga/Marjin Pembiayaan Bersubsidi, Lama Masa Subsidi dan Jangka Waktu Kredit/Pembiayaan Pemilikan Rumah, Batasan Harga Jual Rumah Umum Tapak Dan Satuan Rumah Susun Umum, Batasan Luas Tanah dan Luas Lantai Rumah Umum Tapak, Luas Lantai Satuan Rumah Susun Umum Serta Besaran Subsidi Bantuan Uang Muka Perumahan. 
dank fungsinya maka bank menarik uang yang ada dalam masyarakat yang kurang produktif. Mengurangi uang yang beredar dalam masyarakat berarti berperan langsung menekankan inflasi. Kemudian dari dana tersebut harus disalurkan kepada masyarakat berupa Kredit Kepemilikan Rumah (KPR) dari bank salah satunya.

Dalam implementasi pemberian asuransi kematian Kredit Kepemilikan Rumah (KPR), para pihak antara penanggung dan tertanggung harus memperhatikan hal-hal dasar yang dimana sesuai dalam perjanjian. Menurut ketentuan Pasal 255 Kitab Undang-Undang Hukum Dagang, perjanjian pertanggungan harus dibuat secara tertulis didalam sebuah akta yang disebut polis. Polis ini sebagai alat bukti tertulis bahwa telah terjadi prtanggungan antara penanggung dan tertanggung, didalam polis tersebut disebutkan bahwa semua ketentuan dan persyaratan tentang persyartan yang telah dibuat. ${ }^{15}$

Secara material, dalam perjanjian asuransi adalah satu, apabila sudah tercapai kata sepakat diantara para pihak. Penanggung ataupun tertanggung keduanya sudah sepakat atas semua syarat yang sudah disepakati bersama. Jadi kata sepakat dalam pemberian asuransi jiwa merupakan landasan bagi ada atau tidaknya perjanjian asuransi. ${ }^{16}$ Oleh karena itu jangan sampai keterangan itu kemudian menimblkan kesan bahwa polis itu tidak perlu lagi. Polis itu tetap mempunyai arti yang besar bagi pihak tertanggung, sebab polis itu merupakan bukti yang sempurna tentang apa yang mereka perjanjikan didalam perjanjian pertanggungan itu. Tanpa polis pembuktian terkait sudah atau tidaknya pelaksanaan perjanjian asuransi dalam hal ini adalah asuransi jiwa menjadi sangat sulit dan terbatas.

Sedangkan syarat-syarat formal polis pertanggungan jiwa diatur dalam Pasal 304 Kitab Undang-Undang Hukum Dagang, dalam Pasal tersebut diatur mengenai syarat umum yang harus dipenuhi agar suatu akta dapat disebut polis. Untuk itu ketentuanya menyebutkan beberapa hal yang menjadi isi dari polis pertanggungan jiwa, yaitu:
a. Hari ditutupnya pertanggungan
b. Nama si tertanggung
c. Nama orang yang jiwanya dipertanggungkan
d. Saat mulai berlaku dan berakhirnya bagi penanggung
e. Jumlah uang untuk mana diadakan pertanggungan
f. Premi pertanggungan tersebut.

15 Abdulkadir Muhammad, Pokok-Pokok Hukum Pertanggungan, Bandung: Citra Aditya Bakti, 1990, h. 58.

16 Srirodjeki Hartono, Hukum Asuransi dan Perusahaan Asuransi, Jakarta: SinarGrafika, 2001, h. 123. 
Penerapan kalsifikasi dalam menerima pengajuaan kredit dalam Kredit Kepemilikan Rumah (KPR), mengacu pada Undang-Undang Perbankan yang menegaskan beberapa hal yang harus diperhatikan dalam rangka melindungi dan mengamankan dan masyarakat yang dikelola bank dan disalurkan dalam bentuk kredit, yaitu:

1. Harus dilakukan dengan menggunkana prinsip kehati-hatian

2. Harus mempunyai keyakinan atau kemampuan dan kesanggupan dibitur untuk melunasi hutangnya sesuai dengan yang diperjanjikan

3. Wajib menempuh cara-cara yang tidak merugikan bank dan masyarakat yang mempercayakan dananya pada bank.

4. Harus memperhatikan asas perkereditan yang sehat.

Untuk memperoleh hal yang diuraikan diatas bank harus melakukan penilaian yang seksama terhadap watak, kemampuan modal, dan agunan. Kredit yang telah disetujui dan disepakati antara pihak kreditur dan debitur maka wajib dituangkan dalam perjanjian kredit, bentuk dan format dari perjanjian kredit diserahkan sepenuhnya pada bank yang bersangkutan, namun demikian ada hal-hal yang harus dipedomani dari perjanjian tersebut, agar perjanjian tersebut jelas dan tidak kabur. Perjanjian kredit dalam segi hukum keperdataan merupakan bentuk perjanjian meminjam yang diatur dalam buku ketiga KUHPerdata sebagaimana yang diatur dalam pasal 1754 sampai dengan 1769 KUHPerdata.

Dalam lingkup perbankan ada suatu prinsip yang telah dipegang teguh, yaitu kredit yang dikeluarkan harus dapat diterima kembali sesuai dengan perjanjian. Karena pada dasarnya kepercayaan yang diberiakn tersebut merupakan kepercayaan masyarakat terhadap bank. Dengan demikian, maka bank di dalam mengabulkan suatu permohonan kredit senantiasa selektif, dan apabila bank menerima permohonan kredit dari nasabah, bank perlu melakukan analisis kredit lebih dahulu, analisisnya antara lain:

1. Latar belakang nasabah ${ }^{17}$

2. Prospek usaha yang akan dibiayai

3. Jaminan yang diberikan

4. Hal-hal yang ditentukan oleh bank.

Perjanjian dalam pemberian kredit bank terdapat klausula-klausula, dimana sebagian besar dari klausula tersebut merupakan upaya untuk melindungi pihak kreditur dalam pemberian kredit. Klausula merupakan serangkaian pernyataan yang diformulasikan dalam upaya pemberian kredit bila ditinjaun dari aspek finansial dan hukum. Dari aspek finansial, klausula tersebut melindungi kreditur agar dapat menarik kembali dana yang telah

${ }^{17}$ Gatot Suparmono, Perbankan dan Masalah Kredit, Jakarta: Djambatan, 1995, h. 96 . 
diberikan kepada debitur dalam posisi yang mnguntungkan bagi kreditur apabila kondisi kreditur tidak sesuai dengan perjanjian. dalam aspek hukum klausula merupakan penegakan hukum agar debitur dapat mematuhi substansi yang telah dipastikan dalam perjanjian kredit.

Jadi klausula dalam perjanjian kredit yang dimana salah satunya terkait dengan pemberian KPR, merupakan suatu perjanjian atau janji oleh penerima kredit dalam suatu perjanjian untuk melakukan atau tidak melakukan Tindakan tertentu. Dalam kalusula dapat dikelompokan salah satunya yaitu, mencocokan kredit yang digunakan dalam praktek bisnis yang baik, menyampaikan semua informasi bisnis yang relevan dan data pendukung lainya kepada kreditur, memelihara kondisi keuangan nasabah, memelihara perlindungan atas jaminan dan maksakan perlindungan jaminan kredit yang diberikan struktur kredit, dan kondisi kredit bagi kepentingan kreditur. ${ }^{18}$

Dengan demikian dalam penerapan asransi kematian kredit kepemilikan rumah sebagaimana yang terdapat dalam uraian diatas dituangkan dalam akad kredit yang disebut dengan kredit kepemilikan rumah (KPR). Dalam perjanjian kredit kepemilikan rumah tesebut biasanya dibuat secara notril dihadapan notaris dan biasanya notaris mengikuti draft perjanjian yang telah dibuat oleh para pihak.

\section{Mekanisme Klaim Asuransi Kematian Pada KPR Subsidi}

Salah satu tujuan dari diadakannya perjanjuan asuransi jiwa adalah peralihan resiko dari tertanggung kepada penanggung. Menurut teori pengalihan resiko (risktransfer theory), tertanggung menyadari bahwa ada ancaman bahaya terhadap jiwanya. Jika bahaya tersebut menimpa jiwanya, seseorang akan menderita kerugian atau korban jiwa atau cacat raganya. Secara ekonomi, kerugian atas jiwa atau cacat jasmani akan mempengaruhi hidup serta aktivitasnya. Untuk mengurangi atau menghilangkan beban resiko tersebut, pihak tertanggung berupaya mencari jalan agar ada pihak lain (penanggung) yang bersedia mengambil alih resiko dan sebagai imbalanya dia sanggup membayar kontrak prestasi yang disebut premi. ${ }^{19}$

Tertanggung mengadakan perjanjian asuransi jiwa dengan tujuan mengalihkan resiko yang mengancam jiwanya. Dengan harapan nantinya penanggung apabila terjadi kematian atas diri tertanggung. Akan tetapi untuk mendapatkan pembayaran uang pertanggungan, penerima manfaat yang ditunjuk harus mengajukan klaim pada penanggung terlebih dahulu sesuai dengan syarat yang telah diatur di dalam polis. Pada dasarnya tidak semua permohonan klaim yang diajukan oleh penerima manfaat secara

18 Jhohanes Ibrahim, Mengupas Tuntas Kredit Komersial dan Konsumif Dalam Perjanjian Kredit Bank, Bandung: Mandar Maju, 2004, h. 44.

${ }^{19}$ Abdulkadir Muhammad, op.cit, h. 12. 
otomatis akan dibayar oleh penanggung. Tetapi dalam permohonan tersebut harus dilakukan penelitian sebelumnya. Sehingga dari penelitian tersebut dapat diketahui apakah meninggalnya tertanggung benar-benar diakibatkan oleh pristiwa tidak pasti yang telah disepakati dalam perjanjian asuransi jiwa yang dimuat dalam polis.

Persoalan peristiwa tak tentu atau evenemen erat sekali hubunganya dengan persoalan ganti kerugian. Dalam pasal 204 Kitab Undang-Undang Hukum Dagang yang mengatur tentang isi polis, tidak ada ketentuan keharusan mencantumkan evenmen dalam polis asuransi jiwa. Dalam asuransi jiwa, yang dimaksud dengan bahaya adalah meninggalnya orang yang jiwanya diasuransikan. Meninggalnya seseorang ini merupakan hal yang sudah pasti, setiap makhluk bernyawa pasti mengalami kematian, tetapi kapan meninggalnya seseorang tidak dapat dipastikan, inilah yang disebut pristiwa tidak pasti (evenmen) dalam asuransi jiwa. ${ }^{20}$

Evenmen ini hanya satu, yaitu ketedikpastian kapan meninggalnya sesorang, sebagai salah satu unsur yang dinyatakan dalam definisi asuransi jiwa. Karena evenmen meninggalnya tertanggung itu berisi dua, yaitu meninggalnya itu benar-benar terjadi sampai jangka waktu asuransi, dan benar-benar tidak terjadi sampai asuransi berakhir, kedua-duanya menjadi bahan penanggung. Tuntutan ganti kerugian oleh tertanggung kepada penanggung inilah yang biasanya disebut klaim atau dengan kata lain dapat dikatakan bahwa kalaim adalah tuntutan terhadap hak yang timbulnya disebabkan karena adanya perjanjian asuransi yang telah berakhir.

Besarnya uang santunan yang wajib dibayar oleh penanggung kepada penikmat dalam hal meninggalnya tertanggung sesuai kesepakatan yang tercantum dalam polis. Pembayaran santunan merupakan akibat terjadinya peristiwa, yaitu meninggalnya tertanggung dalam jangka waktu berlakunya asuransi jiwa. Tetapi apabila sampai berakhirnya jangka waktu asuransi tidak terjadinya peristiwa meninggalnya tertanggung, maka tertanggung sebagai pihak dalam asuransi jiwa, berhak memperoleh pengambilan sejumlah uang dari penanggung yang jumlahnya telah ditetapkan berdasarkan perjanjian. ${ }^{21}$

Dalam melaksanakan kewajibannya terkait dengan pembayaran uang pertanggungan (ganti rugi), pihak penanggung harus memperhatikan syaratsyarat khusus yang sudah menjadi standar masing-masing perusahaan asuransi. Penentuan syarat-syarat khusus tersebut juga harus memperhatikan peraturan perundang-undangan, dengan kata lain tidak boleh menyimpang dari peraturan perundang-undang ataupun hukum positif yang berlaku. Untuk penerapan asuransi di Indonesia pihak penanggung menerapkan

\footnotetext{
${ }^{20}$ Ibid., h. 174.

${ }^{21}$ Ibid., h. 175
} 
beberapa procedural klaim yang berbeda, namun secara substansial pada dasarnya mempunyai kesamaan antara satu perusahaan asuransi dengan perusahaan asuransi yang lain. ${ }^{22}$

Dalam lingkup perasuransian, perusahaan asuransi wajib untuk melakukan penyeragaman procedural klaim yang menjadi guidelines bagi tertanggung atau penerima manfaat untuk melakukan klaim. Dengan demikian sebagaimana yang sudah diatur dalam Undang-Undang Nomor 2 Tahun 1992 Tentang Usaha Perasuransian dan diubanh dengan UndangUndang Nomor 40 Tahun 2014 Tentang Usaha Perasuransian, yaitu pembinaan dan pengawasan terhadap usaha asuransi meliputi, penyelenggaraan usaha yang meliputi, syarat-syarat polis asuransi, tingkat premi, penyelesaian klaim, persyaratan keahlian dibidang perasuransian, dan ketentuan-ketentuan lain yang berhubungan dengan penyelenggaraan usaha. $^{23}$

Selanjutnya dalam penjelasan ketentuan pasal 1 ayat (1) huruf $b$ tersebut terkait dengan penyelesaian klaim yaitu, teruntuk dalam rangka pembinaan dan pengawasan, peraturan pelaksanaan yang mencakup maslah penyelesaian klaim akan menetapkan batas waktu maksimum antara saat adanya kepastian mengenai jumlah klaim yang harus dibayar saat pembayaran klaim tersebut oleh penangggung. Dengan demikian mengenai peraturan pelaksanaan klaim yang diatur oleh undang-undang tersebut, perusahaan asuransi sebagai penanggung harus benar-benar mengikuti sebagaimana apa yang sudah diamanat oleh undang-undang.

Selain diatur dalam Undang-Undang Nomor 40 Tahun 2014 Tentang Usaha Perasuransian, Peraturan Pemerintah (PP) Nomor 73 Tahun 1992 Tentang Penyelenggaraan Usaha Perasuransian, yang mana juga telah mengatur sebagai berikut: "perusahaan asuransi dilarang melakukan tindakan yang dapat memperlambat penyelesaian atau pembayaran klaim, atau tidak melakukan Tindakan yang seharusnya dilakukan yang dapat mengakibatkan kelambatan penyelesaian atau pembayaran klaim". ${ }^{24}$

Ketentuan peraturan perundang-undang diatas menjelaskan secara umum bahwa penanggung dilarang mempersulit atau menghambat pembayaran klaim asuransi yang diajukan oleh tertanggung. Tetapi dalam peraturan perundang-undangan tersebut tidak diatur lebih rinci mengenai prosedur pengajuan an pembayaran klaim asuransi khususnya asuransi jiwa.

22 M. Suparman dan Ending, Hukum Asuransi (Perlindungan Tertanggung, Asuransi Deposito, Usaha Perasuransian), Bandung: Alumni, 2003, h. 20.

${ }^{23}$ Pasal 11 ayat (1) huruf b Undang-Undang Nomor 2 Tahun 1992 Tentang Usaha Perasuransian.

24 Pasal 23 Ayat (1) Peraturan Pemerintah Nomor 73 Tahun 1992 Tentang Penyelenggaraan Usaha Perasuransian. 
Mengenai prosedur pengajuan klaim dan pembayaran ditetapkan sendiri oleh penanggung, pada saat menetapkan prosedur pembayaran klaim inilah pihak penanggung dilarang untuk membuat syarat-syarat yang dapat mempersulit tertanggung untuk menerima uang pertanggungan. Sehingga untuk melindungi kepentingan pihak tertanggung dan penerima manfaat dibuatlah perturan perundang-undangan tersebut.

Secara umum mekanisme prosedur klaim asuransi kematian KPR subsidi sama dengan prosedur klaim asuransi jiwa pada umumnya. Perusahaan asuransi sebagai penanggung dalam menetapkan syarat-syarat prosedur klaim pada umumnya dalam beberapa perusahaan hampir sama menerapkan prosedur klaim, dari masing-masing perusahaan adalah kecepatan dan kejujuran dalam menilai suatu klaim. Dalam penentuan apakah perusahaan harus membayar atau menolak suatu klaim maka penilaian mengikuti prosedur penyelesaian klaim. Dengan demikian ada empat langkah pokok dalam prosedur klaim asuransi jiwa, antara lain: ${ }^{25}$

1. Pemberitahuan Klaim

Segera setelah pristiwa yang sekiranya membuat tertanggung mengalami musibah, tertanggung atau pihak yang mewakilinya segera melaporkan kepada penggung, laporan lisan harus dipertegas dengan laporan tertulis. Pada tahap awal ini tertanggung akan mendapatkan petunjuk lebih lanjut mengenai apa yang harus dilakukan oleh tertanggung, dan dokumen apa yang harus dilengkapi oleh tetanggung. Kondisi ini diterapkan untuk memungkinkan pengelola mengambil tindakan apa yang diperlukan mengenai klaim yang muncul. Nasabah dapat memberitahukan klaim baik secara personal kepada pengelola maupun melalui otoritas atas namanya seperti pengecara, broker, atau agen.

2. Bukti Klaim

Peserta yang mendapat musibah diminta menyediakan fakta-fakta yang utuh dan bukti-bukti yang diharuskan perusahaan, karena pada prakteknya masing-masing perusahaan mempunyai kebijakan sendiri dalam menentukan dokumen bukti klaim yang dibutuhkan. Untuk tujuan ini, penting bagi peserta yang mendapat musibah untuk menyerahkan klaim tertulis dengan melengkapi form permohonan klaim. Penting juga penuntut untuk melengkapai dokumen-dokumen yang diajukan sebagaimana yang dipersyaratkan secara standar dalam industri asuransi Indonesia.

3. Penyelidikan

${ }^{25}$ Hasan Ali AM, Asuransi Dalam Prespektif Hukum Islam, Jakarta: Penerbit Kencana, 2004,

h. 90 . 
Setelah laporan yang dilampiri dengan dokumen pendukung diterima oleh penanggung, selanjutnya dilakukan analisa administrasi. Misalnya, mengenai apakah premi sudah dibayar atau belum apabila tahap ini sudah dilalui penanggung akan memutuskan untuk segara melakukan survei lapangan atau menunjuk independent adjuster jika hal itu diperlukan.

4. Penyelesaian Klaim

Setelah terjadinya kesepakatan mengenai jumlah penggantian sesuai peraturan perundang-undangan yang berlaku, diisyaratkan bahwa pembayaran klaim tidak boleh lebih 30 hari sejak terjadi kesepakatan tersebut.

Dengan demikian pengajuan klaim dari tertanggung kepada penanggung pada kenyataannya membutuhkan waktu yang relatif lama sedangkan dalam peraturan perundang-perundang di Indonesia yang mengatur mengenai asuransi mengharuskan agar klaim tersebut secepatnya dapat dibayarkan kepada tertanggung. Proses yang relatif lama tersebut pada dasarnya bertujuan untuk mengetahui secara pasti bahwa tertanggung adalah orang yang berkepentingan atas uang pertanggungan tersebut. Selain itu, proses tersebut juga sebagai bentuk tindakan antisipasif dari penanggung terhadap kemungkinan timbulnya masalah dikemudian hari.

\section{KESIMPULAN}

Dalam implementasi pemberian asuransi kematian Kredit Kepemilikan Rumah (KPR) subsidi, para pihak antara penanggung dan tertanggung harus memperhatikan hal-hal dasar yang dimana sesuai dalam perjanjian. Menurut ketentuan Pasal 255 Kitab Undang-Undang Hukum Dagang, perjanjian pertanggungan harus dibuat secara tertulis didalam sebuah akta yang disebut polis. Secara material apabila sudah tercapai kata sepakat diantara para pihak. Penanggung ataupun tertanggung berarti keduanya sudah sepakat atas semua syarat yang sudah disepakati bersama. Pada KPR Subsidi, pembayaran premi asuransi tidak selalu dibayar diawal sebelum terjadinya akad kredit, namun bisa dilakukan dengan memasukkan pada angsuran kredit.

Mekanisme prosedur klaim asuransi kematian KPR subsidi sama dengan prosedur klaim asuransi jiwa pada umumnya. Perusahaan asuransi sebagai penanggung dalam menetapkan syarat-syarat prosedur klaim pada umumnya beberapa perusahaan hampir sama menerapkan prosedur klaim, dari masing-masing perusahaan adalah kecepatan dan kejujuran dalam menilai suatu klaim. Dalam mekanismenya terdapat beberapa langkah pokok prosedur klaim asuransi jiwa, antara lain, pemberitahuan klaim, bukti klaim, penyelidikan, dan penyelesaian klaim. Penyelesaian klaim asuransi 
jiwa, lembaga asuransi mengganti sisa pokok dari jumlah kreditnya sampai pada bulan ditutupnya kredit, tidak termasuk keuntungan.

\section{DAFTAR PUSTAKA}

\section{Buku}

Abdulkadir Muhammad, 1990, Pokok-Pokok Hukum Pertanggungan, Bandung: Citra Aditya Bakti.

A. Abbas Salim, 1995, Dasar-Dasar Asuransi, Principle of Insurance, Jakarta: RajaGrafindo Persada.

Djoko Prakoso, I Ketut Murtika, 2000, Hukum Asuransi Indonesia, Jakrta: Rineka Cipta.

Emmy Pangaribuan Simanjuntak, I, 1990, Hukum Pertanggungan, Yogyakarta: FH UGM.

Emmy Pangaribuan Simanjuntak, II, 1997, Beberapa Aspek Hukum Dagang di Indonesia, Jakarta: Bina Cipta.

Jhohanes Ibrahim, 2004, Mengupas Tuntas Kredit Komersial dan Konsumif Dalam Perjanjian Kredit Bank, Bandung: Mandar Maju.

M. Suparman, dan Ending, I, 1993, Hukum Asuransi, Bandung: Alumni.

M. Suparman dan Ending, II, 2003, Hukum Asuransi (Perlindungan Tertanggung, Asuransi Deposito, Usaha Perasuransian), Bandung: Alumni.

Man Suparman Sastrawidjaja, 1997, Aspek-Aspek Hukum Asuransi dan Surat Berharga, Bandung: Alumni.

Gatot Suparmono, 1995, Perbankan dan Masalah Kredit, Jakarta: Djambatan.

Hasanuddin Rahman, 1998, Aspek-Aspek Hukum Pemberian Kredit Perbankan Di Indonesia, Bandung: Citra Aditya Bakti.

Hasan Ali AM, 2004, Asuransi Dalam Prespektif Hukum Islam, Jakarta: Penerbit Kencana.

Sri Rejeki Hartono, 2001, Hukum Asuransi dan Perusahaan Asuransi, Jakarta: Sinar Grafika.

Sutomo, 2004, Jaminan Aspek-Aspek Hukum Perkreditan Pada Bank, Bandung: Alfabeta.

Srirodjeki Hartono, 2001, Hukum Asuransi dan Perusahaan Asuransi, Jakarta: SinarGrafika.

\section{Peraturan Perundang-Undangan}

Undang-Undang Nomor 40 Tahun 2014 Tentang Perasuransian.

Undang-Undang Nomor 2 Tahun 1992 Tentang Usaha Perasuransian.

Kitab Undang-Undang Hukum Dagang. 
Peraturan Pemerintah Nomor 73 Tahun 1992 Tentang Penyelenggaraan Usaha Perasuransian.

Keputusan Menteri Pekerjaan Umum dan Perumahan Rakyat Nomor 242/Kpts/M/2020 Tentang Batasan Penghasilan Kelompok Sasaran Kredit/Pembiayaan Pemilikan Rumah Bersubsidi, Besaran Suku Bunga/Marjin Pembiayaan Bersubsidi, Lama Masa Subsidi dan Jangka Waktu Kredit/Pembiayaan Pemilikan Rumah, Batasan Harga Jual Rumah Umum Tapak Dan Satuan Rumah Susun Umum, Batasan Luas Tanah dan Luas Lantai Rumah Umum Tapak, Luas Lantai Satuan Rumah Susun Umum Serta Besaran Subsidi Bantuan Uang Muka Perumahan. 